VERSITA

Acta Veterinaria-Beograd 2014, 64 (1), 73-80

UDK: 636.2.082.22(560) ; 575.224

DOI: $10.2478 /$ acve-2014-0008

Research article

\title{
GENOTYPE AND ALLELE FREQUENCIES OF POLYMORPHISMS IN ABCG2, PPARGC1A AND OLR1 GENES IN INDIGENOUS CATTLE BREEDS IN TURKEY
}

\author{
ATEŞ Atila, TÜRKAY HOŞTÜRK Gülhan, AKIŞ Iraz, ESEN GÜRSEL Feraye, \\ YARDIBI Hasret*, ÖZTABAK Kemal \\ Department of Biochemistry, Faculty of Veterinary Medicine, University of Istanbul, Avc1lar, Istanbul, \\ Turkey
}

(Received 04 January 2014; Accepted 29 January 2014)

\begin{abstract}
This study was carried out to determine polymorphisms of four genes in South Anatolian Red (SAR) and East Anatolian Red (EAR) indigenous cattle breeds in Turkey. Single nucleotide polymorphisms (SNPs) monitored in this study are Y581S in ATP binding cassette sub family $\mathrm{G}$ member 2 (ABCG2) gene, c.1892T $>\mathrm{C}$ and c.3359A $>C$ in peroxisome proliferator-activated receptor gamma coactivator 1 alpha $(P P A R G C 1 A)$ gene and g.8232C $>\mathrm{A}$ in oxidized low-density lipoprotein receptor 1 (OLR1) gene. The frequency of the ancestral allele A of the ABCG2 gene Y581S polymorphism was found to be very high (SAR: 0.63; EAR: 0.64) in both cattle breeds. The CC genotypes of PPARGC1A gene c.1892T >C (SAR: 0.65; EAR: 0.80) and OLR1 gene g.8232C $>$ A polymorphisms (SAR: 0.82; EAR: 0.86), which are associated with high milk fat percentage, had higher frequencies than those of the other genotypes. In conclusion, we might suggest that the allele distribution of the ABCG2 gene Y581S polymorphism can be the evidence indicating autosomal gene flow from zebu cattle to SAR and EAR cattle breeds.
\end{abstract}

Key words: ABCG2 gene, East Anatolian Red, gene polymorphism, OLR1 gene, PPARGC1A gene, South Anatolian Red

\section{INTRODUCTION}

ATP binding cassette sub family $\mathrm{G}$ member 2 (ABCG2) gene, which product is expressed in the mammary gland in cows, encodes a transporter protein that facilitates transport of medicines through the cell membrane by binding ATP. The level of expression significantly increases during lactation compared to the dry period [1]. It has been suggested that this transporter protein plays a role in the secretion of xenobiotics and some micro-nutrients such as cholesterol and vitamin $\mathrm{K} 3$ into milk [2]. ABCG2 gene is located on chromosome 6 in cattle and is known to have important effects on the milk yield traits. A single nucleotide polymorphism (SNP) resulted from translocation of adenine/cytosine on the $14^{\text {th }}$ exon presents the missense mutation named Y581S as it

\footnotetext{
*Corresponding author: e-mail: hasret@istanbul.edu.tr
} 
leads to the replacement of the $581^{\text {th }}$ amino acid tyrosine with cysteine [3].

Another potential Quantitative Trait Locus (QTL) on the $6^{\text {th }}$ chromosome of cattle is Peroxisome Proliferator-Activated Receptor Gamma Coactivator 1 Alpha (PPARGC1A) gene. This gene has been expressed in many organs that are metabolically active. It has been suggested that the product of this gene is associated with cellular energy metabolism, thermogenesis, adipogenesis, and gluconeogenesis [4,5]. Up to date, many SNPs have been determined for this gene [6-8]. However, only two of these have been suggested to have an effect on milk yield traits. The first one is PPARGC1Ac.1892T $>C$ that leads to replacement of threonine/cysteine on the $19^{\text {th }}$ position [6]. The second one is PPARGC1A- c.3359A $>$ C located on 3' UTR region and it causes alanine/cisteine replacement at the 968 position [6].

Oxidized Low-density Lipoprotein Receptor 1 (OLR1) gene encodes surface receptors of vascular endothelial cells and contributes to the balance of low-density lipoproteins [9]. Oxidized low density lipoproteins (ox LDL) cause atherosclerosis and affect glucose and lipid metabolism in the mammary gland $[7,10]$. Naturally, the protein encoded by OLR1 gene affects these metabolisms [8]. OLR1 gene is located on the $5^{\text {th }}$ chromosome in cattle. It has been reported that one SNP located at 3'UTR region is associated with milk yield traits. This SNP resultes from the translocation of cytosine/timine and results in the replacement of cysteine/alanine at the 223th position in the final protein encoded by this gene $[7,8,10]$.

In the present study, genotype and allele frequencies of polymorphisms Y581S of ABCG2 gene, c.1892T $>C$ and c.3359A $>$ C of PPARGC1A gene, and g.8232C $>\mathrm{A}$ of OLR1 gene, which are proposed to have an influence on milk yield parameters, particularly on milk fat percentage, were estimated in South Anatolian Red (SAR) and East Anatolian Red (EAR) cattle breed in Turkey.

\section{MATERIALS AND METHODS}

\section{Animals and DNA isolation}

SAR breed cattle were selected from the herds in South Anatolia whereas EAR cattle were selected from those located in Eastern Anatolia. In the selection of the animals, care was taken not to include animals that were parentally related so they were representative of their own breed characteristics. Blood samples were collected in sterile $2 \mathrm{ml}$ tubes containing EDTA. Genomic DNAs were isolated using a standard ammonium acetate salt-out method [11]. The present study was approved by Istanbul University Local Committee on Animal Research Ethics (25.03.2010; Protocol Nr.:2010/51).

\section{PCR-RFLP Analysis}

The primers and annealing temperatures used to amplify target regions ABCG2 SNP Y581S, PPARGC1A SNPs c.1892T >C and c.3359A >C and OLR1 SNP g.8232C >A are given in Table 1.

The PCR conditions used for all the regions were: initial denaturation at $94{ }^{\circ} \mathrm{C}$ for $5 \mathrm{~min}$, $1 \mathrm{~min}$ at $94{ }^{\circ} \mathrm{C}, 1 \mathrm{~min}$ at the annealing temperature (Table 1$), 1 \mathrm{~min}$ at $72^{\circ} \mathrm{C}$ for 35 cycles 
and a final extension at $72{ }^{\circ} \mathrm{C}$ for $10 \mathrm{~min}$. Amplification was performed in a volume of $25 \mu$ l containing $5 \mu \mathrm{l}$ 10X PCR buffer, $100 \mu \mathrm{M}$ dNTP, 10 pmol of each primer, $1.0 \mu \mathrm{M}$ $\mathrm{MgCl}_{2}, 2 \mathrm{U}$ Taq polimerase (Fermentas Life Sciences, Canada) and 50-100 ng genomic DNA. PCR amplified SNPs Y581S, c.1892T >C, c.3359A $>$ C and g.8232C >A were digested with enzymes Pst $1, B s u R I$, NheI and Pst (Fermentas Life Sciences, Canada), respectively (10 $\mathrm{U}$ of each enzyme) and incubated at $37^{\circ} \mathrm{C}$ overnight. Electrophoretic separation of the digestion products was carried out with $1 \times$ TBE in $2 \%$ agarose gel for 30 min. under $120 \mathrm{~V}$ to differentiate the alleles A (292 bp, uncut) and C (268 and 24 bp); T (193 and 12 bp) and C (173, 20 and 12 bp); A (191 bp, uncut) and C (157 and 34 bp); A (143bp, uncut) and C (118 and $30 \mathrm{bp}$ ), respectively. The gels were subsequently stained with ethidium bromide and photographed on an UV transluminator.

Table 1. Primers and PCR conditions for genotyping of bovine ABCG2, Y581S, PPARGC1A genes and OLR1 gene

\begin{tabular}{|c|c|c|c|c|}
\hline $\begin{array}{l}\text { Locus / } \\
\text { enzymes }\end{array}$ & Primer sequences & $\begin{array}{l}\mathrm{Tm} \\
\left({ }^{\circ} \mathrm{C}\right)\end{array}$ & $\begin{array}{l}\text { Length } \\
\text { of } \\
\text { amplified } \\
\text { fragment } \\
\text { (bp) }\end{array}$ & References \\
\hline $\begin{array}{l}A B C G 2- \\
Y 581 S / \\
\text { Pst } 1\end{array}$ & $\begin{array}{l}\text { F: 5'AACAGCCTCAGCTCCAGAGAGATAT3' } \\
\text { R: 5'CGGTGACAGATAAGGAGAACATACT3' }\end{array}$ & 56 & 292 & $\begin{array}{l}\text { Cohe n - } \\
\text { Zinger et } \\
\text { al. } 2005\end{array}$ \\
\hline $\begin{array}{l}\text { PPARGC1A- } \\
\text { c.1892T>C/ } \\
\text { BsuRI }\end{array}$ & $\begin{array}{l}\text { F: 5'CATAGCCGGCGGCCCAGGTAATGATGCACGTTGGC3' } \\
\text { R: 5'TGGAGCCTTTCGTGCTGGTACTCCTCGTAGCTGTC 3' }\end{array}$ & 69 & 205 & $\begin{array}{l}\text { Weikard et } \\
\text { al. } 2005\end{array}$ \\
\hline $\begin{array}{l}\text { PPARGC1A- } \\
\text { c. } 3359 A>C / \\
\text { NheI }\end{array}$ & $\begin{array}{l}\text { F: 5'GCGAGCACGGTGTTACATTACTAAGGAGAGTTGGCTAG3 } \\
\text { R: 5'GAAGGCTGCATTTACAGTGCA } 3\end{array}$ & 56 & 191 & $\begin{array}{l}\text { Weikard et } \\
\text { al. } 2005\end{array}$ \\
\hline $\begin{array}{l}\text { OLR1 / } \\
\text { PstI }\end{array}$ & $\begin{array}{l}\text { F: 5'TCCСТAACTTGTTCCAAGTCCT3' } \\
\text { R: 5'CTCTACAATGCCTAGAAGAAAGC } 3\end{array}$ & 54 & 143 & $\begin{array}{l}\text { Khatib et } \\
\text { al. } 2006\end{array}$ \\
\hline
\end{tabular}

Tm: Annealing temperature; F: Forward; R: Reverse

\section{Statistical analysis}

Genotype and allele frequencies of ABCG2 SNP Y581S, PPARGC1A SNPs c.1892T >C and c.3359A $>$ C and OLR1 SNP g.8232C $>$ A in SAR and EAR cattle were calculated by using PopGene 32 software [12]. A chi-square test was also performed to check HardyWeinberg equilibrium at each locus by the same program (Table 2).

\section{RESULTS}

The genotype and allele frequencies of $A B C G 2$ gene $Y 581 S$ polymorphism, PPARGC1A gene c.1892T $>\mathrm{C}$ and c.3359A $>\mathrm{C}$ polymorphisms, and OLR1 gene g.8232C $>\mathrm{A}$ polymorphism are given in Table 2. For ABCG2 gene Y581S polymorphism, genotype AA (SAR: 0.50; EAR: 0.62) and allele A (SAR: 0.63; EAR: 0.64) were found high in 
Table 2. The distribution of ABCG2, PPARGC1A and OLR1 gene allele and genotype frequencies of SAR and EAR cattle

\begin{tabular}{|c|c|c|c|c|c|c|c|c|}
\hline \multirow{4}{*}{$\begin{array}{l}\text { Polymorphism } \\
\text { ABCG2 } \\
\text { (Y581S) }\end{array}$} & \multirow[t]{2}{*}{ Breed } & \multirow[t]{2}{*}{$\mathrm{n}$} & \multicolumn{2}{|c|}{$\begin{array}{c}\text { Allele frequency } \\
(\%)\end{array}$} & \multicolumn{3}{|c|}{$\begin{array}{c}\text { Genotype frequency } \\
(\%)\end{array}$} & \multirow[t]{2}{*}{$\left(\chi^{2}\right)^{1}$} \\
\hline & & & $\mathbf{A}$ & $\mathrm{C}$ & AA & AC & $\mathrm{CC}$ & \\
\hline & $\mathrm{SAR}^{2}$ & 49 & 0.63 & 0.37 & 0.50 & 0.28 & 0.22 & $7.6944^{* *}$ \\
\hline & $\mathrm{EAR}^{3}$ & 40 & 0.64 & 0.36 & 0.62 & 0.00 & 0.38 & $41.1682^{*+*}$ \\
\hline \multirow{3}{*}{$\begin{array}{l}\text { PPARGC1A } \\
\text { (T19C) }\end{array}$} & & & $\mathbf{T}$ & $\mathrm{C}$ & TT & TC & $\mathrm{CC}$ & \\
\hline & SAR & 40 & 0.35 & 0.65 & 0.35 & 0.00 & 0.65 & $41.2375^{* * x}$ \\
\hline & EAR & 44 & 0.20 & 0.80 & 0.20 & 0.00 & 0.80 & $46.1893^{*+\infty}$ \\
\hline \multirow{3}{*}{$\begin{array}{l}\text { PPARGC1A } \\
\text { (A968C) }\end{array}$} & & & A & $\mathrm{C}$ & AA & AC & $\mathrm{CC}$ & \\
\hline & SAR & 48 & 0.61 & 0.39 & 0.23 & 0.77 & 0.00 & $18.2946^{* * *}$ \\
\hline & EAR & 35 & 0.70 & 0.30 & 0.40 & 0.60 & 0.00 & $6.0714^{* *}$ \\
\hline \multirow{3}{*}{ OLR1 (C223A) } & & & $\mathbf{A}$ & $\mathrm{C}$ & AA & $\mathrm{AC}$ & $\mathrm{CC}$ & \\
\hline & SAR & 50 & 0.11 & 0.89 & 0.04 & 0.14 & 0.82 & $6.5212^{*}$ \\
\hline & EAR & 50 & 0.09 & 0.91 & 0.04 & 0.10 & 0.86 & $8.7231^{*}$ \\
\hline
\end{tabular}

${ }^{1}$ Hardy-Weinberg equilibrium; 2South Anatolian Red; 3East Anatolian Red; ${ }^{*} \mathrm{p}<0.05,{ }^{*} \mathrm{p}<0.01,{ }^{* * *} \mathrm{p}<0.001$

both SAR and EAR breed cattle. In addition, no AC genotype was found in SAR. For PPARGC1 $A$ gene c.3359A $>$ C polymorphism, high rates of AC genotype (SAR: 0.77; EAR: 0.60) and A allele (SAR: 0.61; EAR: 0.70) were found in both breeds while no CC genotype was detected. For PPARGC1 $A$ gene c.1892T $>$ C polymorphism, high rates of CC genotype (SAR: 0.65; EAR: 0.80) and C allele (SAR: 0.65; EAR: 0.80) were found in both breeds, while no heterozygote TC genotype was detected in neither breeds. As for the OLR1 gene g.8232C>A polymorphism, high rates of CC genotype (SAR: 0.82; EAR: 0.86) and $C$ allele (SAR: 0.89; EAR: 0.91) were found in both breeds (Figure 1). The distribution of genotypes $A B C G 2$ gene $Y 581 S$, PPARGC1 $A$ gene c.1892T $>C$ and c.3359A $>\mathrm{C}$, and OLR1 gene g.8232C $>\mathrm{A}$ were not consistent with the Hardy-Weinberg equation.

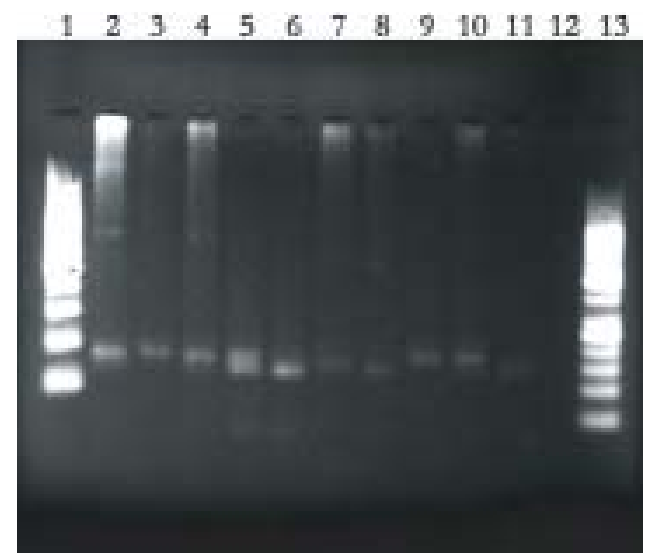

Figure 1. OLR1 genotyping by PCR-RFLP method. Lane 1 and 13, DNA marker (50 bp), lanes 2, 4, 5 and 10 AC genotype; lanes 3 and 9 AA genotypes; lane 6, 7, 8 and 11 CC genotypes 


\section{DISCUSSION}

Considering the genes affecting milk yield and composition traits in cows, it has been suggested that one gene related to these traits exists in all autosomal chromosomes. The most important genes affecting the amount and percentage of milk fat are found on Bos taurus autosomal chromosomes (BTA) 5, 6, 9, 14, 20 and 26 [13]. In the present study, allele and genotype frequencies in the polymorphisms of ABCG2 and PPARGC1A genes that are located on chromosome 6 and OLR1 gene located on chromosome 5 were determined for SAR and EAR cattle reared in Anatolia.

\section{ABCG2 gene}

Ron et al. (2006) studied a total of 35 breeds of Bos taurus (taurin cattle) and Bos indicus (zebu cattle) [14]. The researchers suggested that $A B C G 2{ }^{\mathrm{A}}$ allele could be an ancestral allele because $A B C G 2^{\mathrm{C}}$ frequency was found only in Bos taurus breeds. Based on this, they further proposed that $Y 581 S$ polymorphism could have occurred 200.000 years ago when separation of Bos taurus and Bos indicus cattle breeds took place. Tantia et al. (2006) reported similar findings in Bos indicus breed cattle [15]. In our study, $A B C G 2{ }^{\mathrm{A}}$ allele frequency in SAR and EAR cattle was found to be 0.63 and 0.64 , respectively. These findings support the results by Ron et al. (2006) [14]. Previously, genes frequencies close to Bos indicus breeds were reported for SAR and EAR [16]. In the light of previous studies carried out using data on mitocondrial DNA and $Y$ and autosomal chromosomes [17], this can be explained by the occurrence of a zebu gene flow to the cattle in the near east and remaining of this limited with autosomal genes in Anatolian native breeds.

\section{PPARGCIA gene}

The relationship between c.1892T $>C$ and c.3359A >C SNPs of PPARGC1A gene and milk yield traits was evaluated in many previous studies. However, such relation could not have been proven clearly. Weikard et al. (2005) suggested a relationship between low milk fat level in German-Holstein cattle and the frequency of $\mathrm{C}$ allele at position c.1892T >C [6]. On the other hand, this could not be confirmed by Khatip et al. (2007) in a later study carried out on American Holstein cattle [7].

Alim et al. (2012) reported that milk protein level was higher in Chinese Holstein homozygous cows with TT genotype at the c.1892T $>$ C locus [18]. On the other hand, Komisarrek et al. (2012) reported no relationship between T allele and milk yield traits [19]. Similarly, Kowalewska -Luczak et al. (2010) did not find any relation between c.1892T $>C$ and c.3359A $>C$ polymorphisms of PPARGC1 $A$ gene and milk yield traits in Jersey cattle [20]. In the previous studies, the highest genotype frequency for CC genotype was found 0.68 in German Holstein [6], 0.53 in Polish Holstein-Friesian cattle [8], 0.56 in German Holstein-Friesian [21], 049 in Chinese Holstein cattle [18] while CT genotype was found at the highest frequency of 0.65 in the University of Wisconsin dairy herd [7], and 0.72 in Jersey breed [20]. Kowalewska-Luczak et al. (2010) found the frequency of $P P A R G C 1 A$ gene c.3359A $>C$ polymorphism genotype $\mathrm{AA}$ to bethe highest in the Jersey breed cattle while they did not find genotype CC [20]. In our 
study, CC genotype at the c.3359T $>$ C locus, was found at very high levels as 0.65 and 0.80 in SAR and EAR, respectively while no TC heterozygote genotype was found in neither breed. Although our findings are in agreement with those genotype frequencies reported by Weikard et al. (2005), Komisarek and Dorynek (2009), Schennink et al. (2009), and Alim et al. (2012), distribution of c.1892T >C genotypes varied between the breeds $[6,8,18,21]$. Unlike the findings of Kowalewska-Luczak et al. (2010) in the Jersey breed, AC genotype at the c.3359A $>$ C locus was found at the highest level in SAR and EAR [20]. Nevertheless, parallel to Kowalewska-Luczak et al. (2010), we did not find any individual with CC genotype.

\section{OLRI gene}

Previous studies indicated that OLR1 genotypes have important effects on the amount and percentage of milk fat [7,10,21]. Khatip et al. (2006) reported that CC genotype and $\mathrm{C}$ allele significantly increased the amount and percentage of milk fat in the Holstein breed cattle [10]. They suggested that 3'-UTR polymorphism of OLR1 gene plays an important role in the expression and translocation of the gene and OLR1 expression and synthesis of OLR1 was particularly higher in genotype CC. These findings were supported by similar results reported by Khatip et al. (2007) on Italian-Swiss Brown cattle and on Holstein herd at the University of Wisconsin [7], and by Schennink et al. (2009) on German Holstein-Friesian cattle herd [21]. In our study, CC genotype frequency was found 0.82 and $\mathrm{C}$ allele was 0.89 in SAR while they were very high, 0.86 and 0.91, respectively, in EAR cattle. Khatip et al. (2006) found C allele frequency as 0.54 in Holstein breed cattle while they reported the frequency as 1.00 in Bison bison, Swiss Brown, and Jersey breeds, and as 0.87 for Guernsey breed cattle [10]. Khatip et al. (2007) also reported C allele frequency to be 0.95 and 0.64 in Italian-Swiss Brown and Holstein dairy herd (University of Wisconsin-Madison), respectively [10]. Schennink et al. (2009) found C allele frequency to be 0.71 in German Holstein-Friesian cattle [21]. Finding higher frequencies of $\mathrm{C}$ allele in Bison bison, Swiss Brown, Jersey, and ItalianSwiss Brown cattle compared to that found in Holstein breed cattle was interpreted as higher milk fat percentage in those breeds than those seen in Holstein [10,21]. C allele frequencies of SAR and EAR breeds were found close to those of Bison bison, Swiss Brown, Jersey, and Italian-Swiss Brown cattle. Thus, we can suggest that this similarity is because of higher milk fat percentage of SAR and EAR.

In conclusion, in respect to Y581S polymorphism of ABCG2 gene, SAR and EAR cattle were found to be closer to Bos indicus breeds. This finding is in agreement with the results of the previous study that indicated zebu gene flow to these two breeds along with autosomal gene findings. In addition, in terms of genotypes and alleles of SNPs c.1892T $>$ C of PPARGC1 A gene and g.8232C >A of OLR1 gene, these two breeds were found close to other cattle breeds with higher milk fat percentage. These findings are parallel to the fact explaining the higher milk fat percentage in these two native breeds.

\section{ACKNOWLEDGEMENT}

This study was supported by the Research Fund of Istanbul University, Project no: 6627. 


\section{REFERENCES}

1. Farke C, Mayer HH, Bruckmaier RM, Albrecht C: Differential expression of ABC transporters and their regulatory genes during lactation and dry period in bovine mammary tissue. J Dairy Sci 2008, 75:406-414.

2. Van Herwaarden AE, Wagenaar E, Merino G, Jonker JW, Rosing H, Beijnen JH, Schinkel AH: Multidrug transporter ABCG2/breast cancer resistance protein secretes riboflavin (vitamin B2) into milk. Mol Cell Biol 2007, 27:1247-1253.

3. Cohen-Zinder M, Seroussi E, Larkin DM, Loor JJ, Everts-van der Wind A, Lee JH: Identification of a missense mutation in the bovine ABCG2 gene with a major effect on the QTL on chromosome 6 affecting milk yield and composition in Holstein cattle. Genome Res 2005, 15:936-944.

4. Puigserver P: Tissue-spesific regulation of metabolic pathways trough the transcriptional coactivator PGC1-alpha. Int J Obes 2005, 29:5-9.

5. Linang H, Ward WF: PGC-1alpha: a key regulator of energy metabolism. Adv Physiol Educ 2006, 30:145-151.

6. Weikard R, Kühn C, Goldammer T, Freyer G, Schwerin M: The bovine PPARGC1A gene: molecular characterization and association of an SNP with variation of milk fat synthesis. Physiol Genomics, 2005, 21:1-13

7. Khatip H, Zaitoun I, Wiebelhaus-Finger J, Chang YM, Rosa GJM: The association of bovine PPARGC1A and OPN genes with milk composition in two independent Holstein cattle populations. J Dairy Sci 2007, 90:2966-2970.

8. Komisarek J, Dorynek Z: Effect of ABCG2, PPARGC1A, OLR1 and SCD1 gene polymorphism on estimated breeding values for functional and production traits in polish Holstein-Friesian bulls. J Appl Genet 2009, 50:125-132.

9. Metha JL, Li D: Identification, regulation and function of a novel lectin-like oxidized lowdensity lipoprotein receptor. J Am Coll Cardiol 2002, 39:1429-1435.

10. Khatip H, Leonard SD, Schutzkus V, Luo W, Chang YM: Association of the OLR1 gene with milk composition in Holstein dairy cattle. J Dairy Sci 2006, 89:1753-1760.

11. Miller M, Dykes DD, Polesky HF: A simple salting out procedure for extracting DNA from human nucleated cells. Nucleic Acids Res 1985, 16:1215-1219.

12. Yeh, F, Yang RC, Boyle T: Popgene (v. 1.32): Microsoft Windows-based freeware for Population Genetic Analysis. [http://www.ualberta.ca/ fyeh/popgene_download.html]

13. Khatkar MS, Thomson PC, Imke T, Herman WR: QTL mapping in dairy cattle: review and meta-analysis. Genet Sel Evol 2004, 36:163-190.

14. Ron M, Cohen-Zinder, M, Peter C, Weller JI, Erhardt GA: Polymorphism in ABCG2 in Bos indicus and Bos taurus cattle breeds. J Dairy Sci 2006, 89:4921-4923.

15. Tantia MS, Vijh RK, Mishra BP, Mishra B, Kumar B, Sodhi M: DGAT I and ABCG2 polymorphism in Indian cattle (Bos indicus) and Buffalo (Bubalus bubalis) breeds. BMC Vet Res 2006, 2:1-5.

16. Akis I, Oztabak K: Bos indicus associated alleles in Anatolian cattle breeds support zebu introgression into Near East. J Biol Res -Thessalon 2013, 19:131-138.

17. Edwards CJ, Baird JF, MacHugh DE: Taurine and Zebu admixture in Near Eastern cattle: A comparison of mitochondrial, autosomal and Y-chromosomal data. Anim Genet 2007, 
38:520-524.

18. Alim MA, Fan Y, Xie Y, Xiaoping W, Sun D, Zhang Y, Zhang S, Zhang Y, Zhang Q, Liu L: Single nucleotide polymorphism (SNP) in PPARGC1A gene associates milk production traits in Chinese Holstein Cattle. Pak Vet J 2012, 32:609-612.

19. Komisarek J, Walendowska A: Analysis of the PPARGC1A gene as a potantial marker for productive and reproduktive traits in cattle. Folia Biol-Karakow 2012, 60:171-174.

20. Kowalewska-Luczak I, Kulig H, Kmiec M: Associations between the bovine PPARGC1A gene and milk production traits. Czech J Anim Sci 2010, 55:195-199.

21. Schennink A, Bovenhuis H, Leon-Koosterziel KM, van Arendonk, JAM, Visker MHPW: Effect of polymorphisms in the FASN, OLR1, PPARGC1A, PRL and STAT5A genes on bovine milk-fat composition. Anim Genet 2009, 40:909-916.

\title{
GENOTIPSKE I ALELSKE FREKVENCIJE POLIMORFIZAMA U ABCG2, PPARGC1A I OLR1 GENIMA KOD DOMAĆIH RASA GOVEDA U TURSKOJ
}

\author{
ATEŞ Atila, TÜRKAY HOŞTÜRK Gülhan, AKIŞ Iraz, ESEN GÜRSEL Feraye, \\ YARDIBI Hasret, ÖZTABAK Kemal
}

Studija je obavljena u cilju određivanja polimorfizma četiri gena kod južne anadolijske crvene (SAR) i istočne anadolijske crvene (EAR) domaće rase goveda u Turskoj. Pojedinačni nukleotidni polimorfizmi (SNPs) koji su posmatrani u ovoj studiji su Y581S u ATP vezujućoj kaseti podfamilije G člana 2 (ABCG2) gena, c.1892T $>$ C i c.3359A >C u PPARGC1A genu i g.8232C>A u genu za oksidisani lipoproteinski receptor male gustine (OLR1). Ustanovljeno je da je učestalost polimorfizma alela A predaka ABCG2 gena Y581S veoma visoka (SAR: 0.63; EAR:0.64) i to kod obe rase goveda. Učestalost polimorfizama CC genotipova PPARGC1A gena c. 1982T $>$ C (SAR: 0.65; EAR: 0.80) i OLR1 gena g.8232C>A (SAR: 0.82; EAR: 0.86) koji su povezani sa visokim procentom masti u mleku, bile su veće u poređenju sa drugim genotipovima. U zaključku može da se sugeriše da distribucija polimorfizma alela ABCG2 gena Y581S može da bude pokazatelj putanje autozomnog gena od zebu govečeta do SAR i EAR rasa goveda. 